\title{
CANADA'S DRIVE FOR BETTER HOUSING
}

\author{
BY THOMAS ADAMS \\ Housing and Town Planning Adviser to the Canadian Govonment
}

\begin{abstract}
While numerous American states and cities have been rather helplessly and tardily appointing commissions to investigate the shortage of housing and cessation of building, Canada was in action within a few days of the armistice. This material was presented also at the National Conference on Social Work at Atlantic City in June.
\end{abstract}

IN Canada we did not attempt to carry out any government housing during the war. That was our misfortune in one respect since it prevented us using the energy and restlessness that comes during periods of war, as a means of creating some bold experiment in model housing.

On the other hand it is our good fortune that our present position is not prejudiced by the carrying out of any extravagant and hurried scheme during the war; by extravagant, of course, I mean the necessary extravagance created by war conditions.

\section{HOUSING AS A PROBLEM OF POST-WAR RECONSTRUCTION}

Since the war ceased we have started, in Canada, to deal with housing as a national affair and as a problem of reconstruction. In that sense I believe the United States is still without any definite policy. In my opinion the Canadian policy in this matter is based on the soundest principles that can be applied under a federal constitution in a democratic country. Of course it is not in any sense final. It is a beginning and I am certain that, if we apply proper administration, it will be a beginning of very great things.

In the inauguration of an entirely new policy, involving almost revolutionary changes in sentiment and practice, it is better to begin cautiously and with moderate expectations, only making sure that the principles are sound and that whatever is done is a contribution towards the complete administrative whole it is sought to attain. It is desirable also to use public enterprise as a stimulus and aid to good private enterprise and not as an alternative to anything but bad private enterprise.

\section{THE CANADIAN NATIONAL HOUSING PROJECT}

The armistice was signed on November 11. Immediately afterwards representatives of the federal and provincial governments of Canada met and, among other subjects, discussed the desirability of creating better housing conditions. It was observed that there had been a practical cessation of building operations during the war and a scarcity of housing accommodation. The privy council only reported on the matter on December 2, and on the following day, December 3, an order-in-council was issued granting a loan of $\$ 25,000,000$. On December 12, a committee of five members of the cabinet was appointed 
to administer the loan. Prior to the taking of this action by the dominion government, the provincial government of Ontario had decided to appropriate $\$ 2,000,000$ for housing in Ontario as an addition to any federal loan that might be given.

The federal loan of $\$ 25,000,000$ will be distributed among the nine provinces of Canada, pro rata to the population. It is hoped that each province will add a contribution of its own so as to make the available total much larger. The money will be lent at 5 per cent to the provinces and will be repayable by them, in most cases, in six monthly equal installments of principal and interest.

I will now deal briefly with the administration of the loan under two heads:

First, the administrative machinery, and

Second, the conditions and principles under which state-aided housing schemes will be carried out.

\section{ADMINISTRATIVE MACHINERY}

The federal government, the provincial governments and the municipalities are all involved in the machinery that has to be set up to carry out housing schemes.

Under the constitution of Canada the duty of providing houses and controlling land development is a provincial and municipal, and not a federal matter. Many have urged that the federal government should itself carry out housing schemes, but this would interfere with the autonomy of both the provinces and the municipalities. For the sake of the future development of government housing and its successful administration, it is essential to pay full regard to this fact. In the working out of the administrative machinery great care has been taken to avoid anything that would have the appearance of interfering with the local government. At the same time it is obviously essential that the federal government should take some responsibility with regard to the way in which their money is to be used. They certainly should give some leadership and guidance on the subject and afford an opportunity for co-ordinating the work of the various provinces.

As we shall see later, each province has, before getting the loan, to submit a general provincial scheme of housing for the approval of the federal government. Some kind of federal organization is necessary to examine these schemes, to report on them, and subsequently to exercise some oversight to see that they are carried out. All this must be done with great care and tact as a means of assisting the provincial governments, rather than as a means of criticising anything they do. Once each provincial scheme is approved by the federal government, the jurisdiction in respect of all local schemes will rest with the provincial authorities. In the same way it is expected that as a rule the provincial authorities will show a similar confidence in the municipalities and that once the municipal scheme of housing is settled the municipality will be left comparatively free to administer it and to obtain such loans as it requires to be spent in conformity with the scheme.

To put it briefly, the machinery represents complete co-operation between the federal, provincial and municipal governments with the responsibility divided as follows:

(a) Federal-Responsibility for approval of general schemes of each province dealing with the standards and conditions to be imposed by the province in making loans to municipalities; carrying out of advisory work 
in connection with provincial legislation, forms of scheme, and preparation of plans and specifications, etc., and reporting on questions relating to standardization, comparative data collected from different provinces, ete.

(b) Provincial-Responsibility to repay loan to federal government and to administer the general scheme it has prepared and to secure from each municipality bolrowing money a general municipal scheme for its own area.

(c) Municipal-Responsibility for repaying loan to the province and supervising and carrying out all housing schemes in accordance with the principles and standards included in the municipal scheme which is part of, or consistent with, the general provincial scheme.

The result of the procedure is that the real work and the real responsibility rests with the municipality, although in many cases commissions appointed in municipalities have to, or in some cases may be, appointed. At any rate the responsibility is local. It is near to the people. Close observation of the working out of details will be best attained by this means. It is likely that the municipalities will be slow to accept the responsibility. This has proved to be a stumbling block to housing progress in most countries where national housing has been carried out. It is also probable that some people will fear that our municipal administrations are not competent to undertake such additional responsibilities.

Undoubtedly there are defects in our municipal councils and forms of government and we can always find good reasons for withholding the giving of any added duties or powers to our municipal administrators, but I shall hazard the statement that the longer we continue to do that the longer we shall have to wait to get local bodies in whom we can have confidence. My own opinion is that we should pile up responsibility on the municipal authority for all matters of local administration; that we should not attempt to supersede them more than is necessary for purposes of co-ordination and general progress and that, even if this does produce mistakes, these mistakes will, on the whole, be less than if we attempted to centralize the machinery of the government too much and to create new forms of bureaucracy.

The actual progress made up to the present is that a federal office has been opened in which there are town planners, engineers and architects engaged in collecting data, preparing reports on different aspects of housing and town planning; preparing model plans for distribution to the provinces and municipalities; acting as a clearing house for information on all phases of the housing question; inquiring into questions of shortage of houses, etc. This office is in direct communication with the administrative departments of each of the provinces. The order-incouncil setting out the dominion scheme was not completed and issued until each province had an opportunity of raising objections, the result being that the federal scheme was practically agreed to by all the provinces before it was made public. Since this federal scheme was issued, on February 20, the following provinces have passed acts of parliament to take advantage of the loan and deal with the procedure necessary for that purpose: Nova Scotia, Prince Edward Island, New Brunswick, Quebec, Ontario, Manitoba and British Columbia, leaving only two provinces which have, so far, not joined in the government scheme, for reasons that are local and not because they object to the scheme in any principle. 
In four out of these seven provinces, general schemes of housing have been prepared and, in the other three, schemes are in course of preparation.

In Quebec and Ontario, directors of housing have been appointed and steps to create special officials are also being taken in the other provinces.

I am not able to enter into many details regarding the progress made, but will simply quote the latest report of the director of housing of the one province of Ontario, which names forty-seven municipalities which have passed the necessary by-laws bringing them under the provisions of "The Ontario Housing Act, 1919."

The Report says further:

"About five hundred plans have been approved by the director of the bureau of municipal affairs, and in a considerable number of the above mentioned municipalities houses are under construction.

"The director estimates that the loans required by these municipalites will aggregate nearly $\$ 10,000,000$.

"About twenty municipalities are considering plans for acquiring land and erecting houses on a large scale. Some of them have already purchased land."

The largest city in the Province (Toronto) is not included in the list. It is preparing a scheme of its own under special powers, and purposes to carry it out by means of municipal bonds raised for the purpose.

I would refer those who are interested in obtaining further information to the report of the Ontario housing committee which contains a number of plans for use, if desired, by municipalities, and also to the regulations and forms of the Ontario province, both of which publications can be obtained from Mr. J. A. Ellis, Director of Housing, Parliament Buildings, Toronto.

You will see from the dates I have used and the progress already made that the process of joint co-operation of the three sets of government does not lead to any serious delay in administration.

\section{STANDARDS AND GENERAL PRIN- CIPLES OF SCHEMES}

In the order-in-council of February 20, the standards and principles of the federal scheme were set forth. The general object was stated to be as follows:

(a) To promote the erection of dwelling houses of modern character to relieve congestion of population in cities and towns; (b) to put within the reach of all working men, particularly returned soldiers, the opportunity of acquiring their own homes at actual cost of the building and land acquired at a fair value, thus eliminating the profits of the speculator; (c) to contribute to the general health and wellbeing of the community by encouraging suitable town planning and housing schemes.

\section{FOUR CONDITIONS OF FEDERAI SCHEME TO BE COMPLIED WITH BY PROVINCES}

Four conditions were attached to the proposed loan as follows:

(1) The general housing scheme had to be approved as already stated. It was required that the general scheme should include a schedule of minimum standards for purpose of health, comfort and convenience.

(2) Loans were restricted to $\$ 3,500$ for frame or veneered dwelling, and $\$ 4,500$ for dwellings of more durable construction as specified.

(3) Money could only be loaned to the provinces and municipalities, housing societies or companies with dividends limited to 6 per cent, and owners of lots for erecting houses for their own occupancy.

(4) The period was fixed to twenty years for local improvements such as 
pavements, and frame or veneered buildings; and thirty years for land and more permanent buildings. Due regard is paid to the life of the improvements with a view to encouraging more permanent construction. Thus a loan of $\$ 3,000$ for a frame dwelling for twenty years would cost about the same per month as a loan for a better house costing $\$ 4,000$ for thirty years.

These are the four conditions, but attached to the government project are a number of recommendations with regard to standards. Some of the provinces are adopting these recommendations merely as suggestions to be made by them to the municipalities. Others are adopting them and making them compulsory, and others are going further in some respects and not so far in others.

RECOMMENDATIONS OF FEDERAL GOVERNMENT AS TO STANDARDS

I shall have to refer you to the federal scheme, a copy of which I shall be pleased to forward to any applicants, for the details of the standards, and will only draw attention to a few of the outstanding points. The standards set forth are very general and do not enter into much detail. The object was to secure the things that are essential, and that are usually overlooked in municipal by-laws.

They comprise recommendations that land be acquired by a speedy method at the lowest cost; that sites be properly planned and that local improvements, sewers and water supply, be provided in advance of the building of houses; that one tenth of all areas for housing schemes be reserved for open spaces; that not more than one tenth, and in no case than one eighth, of the gross cost per dwelling be spent on bare land; that certain standards be applied to the sizes of rooms, distances between buildings and to sanitary conditions. For instance, every house should have a bathroom.

\section{PROPORTION OF COST OF LAND TO COST OF IHOUSE}

With regard to the suggestion that the cost of land should be fixed in proportion to the cost of the dwelling, the reference is to the land in an unimproved condition, but if pavements, sewers and water-mains are constructed it would mean that the proportion of the site of the dwelling might be a fourth or a fifth instead of an eighth or a tenth.

So far as the bare land is concerned, no workman's house should be erected on land that in an unimproved conditions costs more than an eighth or a tenth of the complete dwelling. One of the curious facts is that the provinces where land is most plentiful in relation to population are finding it most diffcult to comply with this suggestion. In one of the old towns of Ontario, land is being obtained for building houses at \$20 per lot, which will represent about a hundred and fiftieth part of the cost of the completed building inclusive of land and local improvements. The effect of this will be that the purchaser will be able to spend an extra $\$ 200$ on his house more than he could have done on land costing the ordinary price in a small town. This $\$ 200$ will go to supply those improved sanitary facilities that are usually left out through lack of means caused by the excessive cost of the site.

\section{CANADIAN SCHFME SUITABLE FOR UNITED STATES CONDITIONS}

I commend the Canadian scheme as an example that might very well be followed in the United States. You, too, should have your federal office of 
housing and town planning, a co-ordinating and advisory bureau. The war has been won by organization as well as by the valor of our men. If it had gone on a few months longer you would have wasted more than you now need to spend in solving your housing problem. Your federal govermment should offer a sum of money which, to be equivalent to the Canadian appropriation, would be about $\$ 300,000,000$ to assist the states to carry out housing and town planning schemes. This money should be lent at 4 per cent to be equivalent to our 5 per cent. It should be lent to your state governments after consultation with them, and after settlement with them of the principles that would govern the spending of the money on housing schemes. Each state would prepare its own housing scheme, and one main condition of any federal scheme should be that such a state scheme be prepared and approved before any loan is granted. Under state control the municipalities or housing commissions would work out the problem locally and would build houses where needed.

To make housing improvement more effective, however, it will be necessary to have better and more general town planning legislation in the states and to unite administration of housing and town planning together in a state department.

It seems difficult to believe that the American people, with all their resourcefulness, their love of freedom and humanity and their unequalled opportunities, will let their program of reconstruction continue to have the defect that it does not deal adequately with the most pressing social problem of our time. All of us realize what the housing problem is to-day in our big cities. In New York and Montreal it is getting beyond our control-by any means within our power. Let us ask ourselves what the problem will be in twenty years hence when the slum population has multiplied more rapidly than other classes of population, and our slum areas have grown relatively greater than now to our healthy areas, and the great cities are spread over double their present territory. There is hardly another social question to which it is more important that we should apply our energies, and there are few other social problems that can be effectively dealt with, without at the same time dealing with the problem of improving housing conditions. 